\title{
Environmental Logistic Management, Stakeholders Pressures and Sustainable Performance
}

\author{
D.O.I - 10.51201/Jusst12577 \\ http://doi.org/10.51201/Jusst12577
}

\author{
Ahmed A. Zaid ${ }^{1 *}$, Mohammad Sleimi ${ }^{2}$, Nour Alaqra ${ }^{3}$ \\ ${ }^{1}$ Department of Industrial Management, College of Business and Economics, \\ Palestine Technical University-Kadoorie, Tulkarm, Palestine, (*Corresponding \\ Author). \\ Department of Industrial Management, College of Business and Economics, \\ Palestine Technical University-Kadoorie, Tulkarm, Palestine. \\ 3 \\ Faculty of Administrative and Economic Sciences, Al-Quds Open University, \\ Palestine.
}

\begin{abstract}
Recently, manufacturing firms faced pressure from stakeholders to adopt environmentally friendly business practices, as it became necessary to identify environmental practices that enhance sustainability performance. As growing amount of studies have focused on environmental logistic management (ELM) practices that incorporate ecological thinking, these practices are expected to affect environmental impact of organizations. The aim of this study is to review the various literatures on the relationship between ELM practices, stakeholders pressure and sustainability performance. Furthermore, this study aims to propose a reasonable conceptual model to clarify the relationship between these three variables in the context of the Palestinian manufacturing sector. The research findings will be specifically imperative for manufacturing organizations with the aim of improving their sustainability.
\end{abstract}

Keywords: Environmental Logistic Management, Stakeholders Pressure, Sustainability Performance.

\section{INTRODUCTION}

In general, environmental issues and the provision of environmentally friendly products and the role of companies in achieving sustainable development in Palestine are some of the most important growing issues in light of a highly complex local and international environment, where the role of pressure from stakeholders such as the government and civil society organizations is increasing to push Palestinian industrial organizations to provide environmentally friendly products and take into account environmental requirements. In its industrial operations and also in response to the rules and requirements for Palestinian products to enter international markets[1]. Interest has increased in the recent period in the concept of environmental logistic management (EML) due to the increase in interest in environmental issues and the role of organizations in achieving sustainable development and stakeholders. In recent times, organizations have had a major role in programming and designing their operations in a manner consistent with environmental requirements and meeting stakeholders in providing environmentally friendly products as well as considerations [2]. Competitiveness, had a great role in seeking to satisfy all concerned parties, whether organizations or stakeholders, government, suppliers, 
higher management, employees, customers in adopting the concept of development and environmental awareness [3]. Recently, most manufacturing firms are facing increasing pressure from stakeholders and environmental organizations to concern themselves with ecological issues (i.e., reducing carbon emissions, reducing fossil fuels, providing environmentally friendly products), which led to these pressures being reflected on their strategies. Operational and on its own logistic management practices in order to be able to meet those environmental demands and pressures by environmental organizations and stakeholders [4,5].Therefore, most recent researches in the field of logistic management have tended to identify the most important (green) ecological practices within logistic management in addition to how to create a cooperative and complementary relationship between manufacturing firms and stakeholders in order to reduce carbon emissions, reduce high pollution rates, and encourage operations [6]. As a result, it is worth signifies the need to further explore whether stakeholder's pressure could mediate the ELM practices and sustainable performance relationship in order to achieve a long-lasting competitive advantage for organizations. In particular, this paper suggests that exploring potential relationships between EML practices and stakeholder pressure will lead us to formulate a conceptual relational model. This conceptual model may help explain in depth their impact on sustainability performance, besides providing insightful implications for both theory and practice. However, any new contribution in this field of study will lead to gain a considerable improvement in environmental protection and sustainable development for manufacturing organizations.

\section{PROPOSED CONCEPTUAL MODEL}

In consort with the supports that have been identified from the prior literature, a theoretical framework is suggested to investigate the relationship between ELM practices, stakeholders pressure and sustainability performance in the proposed model, as shown in Figure 1. In this research, we classified ELM practices into five practices (i.e., environmental cooperation, environmental purchasing, reverse logistics, internal environmental management and eco-design) [7]. The stakeholders' pressures were classified to internal and external pressures. In particular, this study considers. In this research, we focus on two specific types of stakeholders that are of critical importance when considering environmental issues: customers and regulatory stakeholders. We argue that the pressures from these two types of stakeholders on environmental issues lead the firm to improve its environmental performance for two different reasons [8]. Lastly, the sustainability performance is investigated from the perspectives of economic, environmental, and social.

\section{HYPOTHESIS DEVELOPMENT}

Concerning ELM practices, previous literature has shown a positive impact on environmental performance [9]. For instance, Green et al. [10] found that ecodesign and internal environmental management result in the improved environmental performance of the manufacturing industries in the US context. Diabat et al. [11] found that a positive relationship between environmental purchasing, reverse logistics and cooperation with customers, and environmental performance. Recently, many empirical studies have found a positive relationship between ELM practices and economic performance that lead to gain a competitive advantage for a firm [12]. For example, Koh et al. [13], found that eco-design 
implies the reduction of waste and efficient use of materials leads to cost savings which positively affects the economic performance of the firm. Holt and Ghobadian [14] found ELM practices such as environmental purchasing leads to economic performance (cost savings, increase in profit, sales, and market share). Despite that empirical studies on the relationship between ELM practices and social performance are limited in the literature [15] the available empirical evidence shows that eco-friendly practices in general, have a considerable social performance such as customer loyalty and enhancing corporate image [16]. Indeed, the pressure exerted by stakeholders on business organizations began to increase in order to reduce negative impacts on the environment across the supply chain. Zhu et al [7] identified the most important sources of pressure from stakeholders within the supply chain in governmental and international legislation, customer and supplier pressures, and internal pressures to adopt and applying strategies targeting clean or green design and production [17]. Cheng et al. [18] confirmed that the most influential and interacting stakeholders on the organization in supply chain relationships are suppliers, customers and competitors, and this necessarily requires finding and building a mechanism to bring about cooperation with these parties through building trust, participation and mutual learning on environmental issues. Hofer et al. [17] also emphasized that there is an increase in the influence of these groups on industrial organizations to meet their demands in terms of protecting the environment, achieving sustainability in resources and providing environmentally friendly products. This is what prompted industrial organizations to design internal and external practices that are capable of meeting the expectations of stakeholders and satisfying their environmental expectations. Indeed, manufacturing organizations must design and plan their operations and logistical activities on how to achieve environmental requirements and meet the demands of stakeholders in providing environmentally friendly products and practicing activities directed at environmental considerations and a culture of environmental protection and achieve sustainability [19], as the essence of sustainable performance revolves around meeting the company's current needs. And the future of the resources without causing any harm to the environment in the production and provision of products and meet the needs and work on compatibility with the pressures of stakeholders [20].

Based on the above literature review, we propose the following hypotheses:

H1: The ELM practices is positively related to sustainability performance.

H2: Customer pressure is positively related to sustainability performance.

H3: Regularity stakeholder pressure is positively related to sustainability performance.

H4: The ELM practices positively affect External customer pressure.

H5: The ELM practices positively affect regularity stakeholder pressure.

H6: Customer pressure can play mediating role between ELM practices and sustainability performance.

H7: Regularity stakeholder pressure can play mediating role between ELM practices and sustainability performance. 


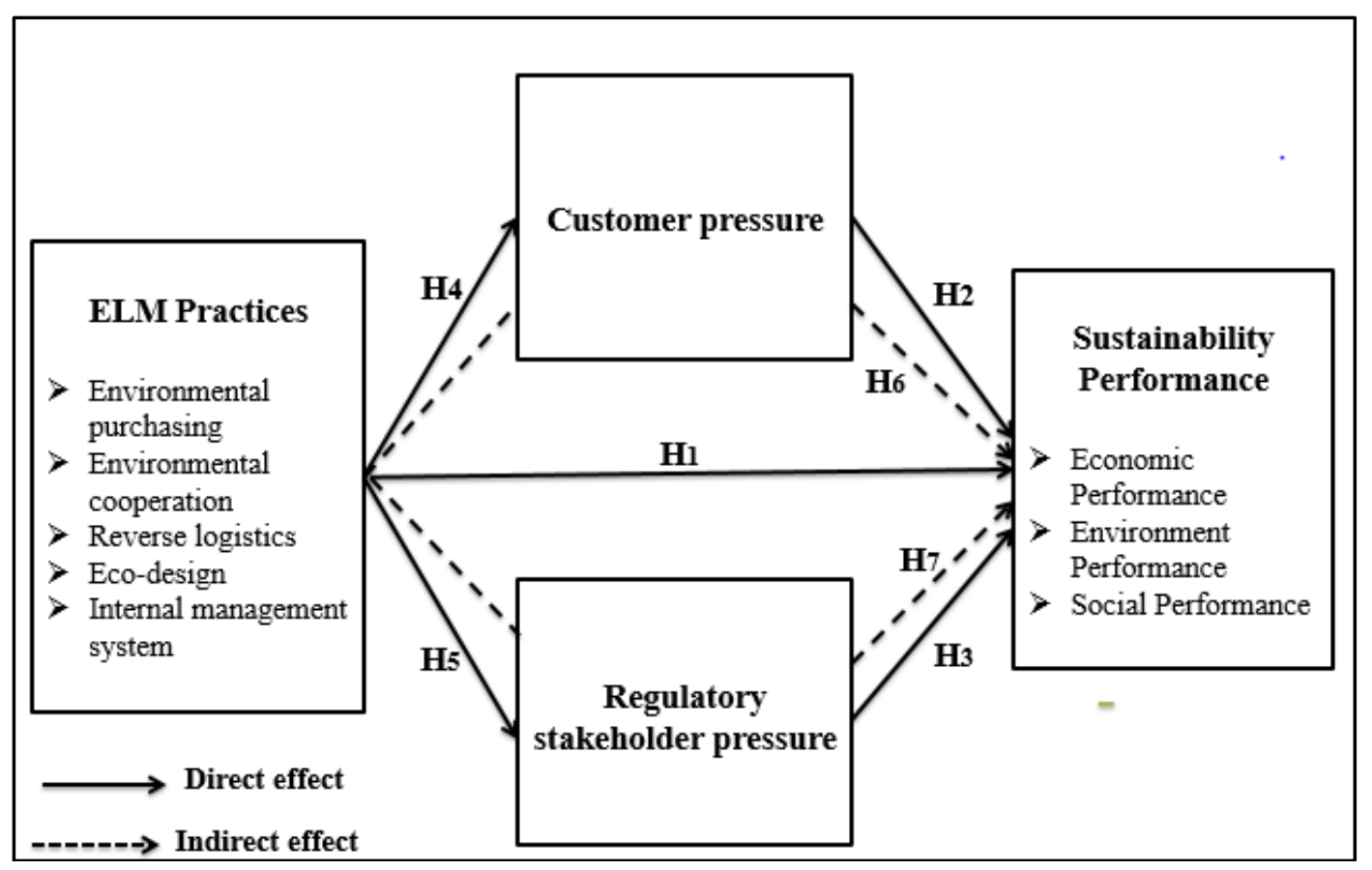

Figure 1: Research Framework

\section{SAMPLE, DATA COLLECTION.}

The population for this study is senior executives who are responsible for ELM practices in Palestinian manufacturing firms. They are those having a good understanding of the variables. The study will invite 300 firms that are members of the Palestinian Industrial Federation representing the most industrial pollutant sectors such as food, pharmaceuticals, and chemicals [21]. The criteria of the participating firms are manufacturers that implement green practices. Of 300manufacturing firms, 170 of them adopt environmental practices. The sample size of 170 is considered adequate for performing data analysis using SEM-Partial Least Squares (PLS) [22]. A survey is designed to measure ELM practices, stakeholder pressure and sustainability performance. PLS-SEM will be employed to test research hypotheses. It is a second-generation multivariate analytical tool for identifying a new theory (EML in the Palestinian context). SEM-PLS can determine the hypotheses and statistical properties of a conceptual framework, simultaneously [22]. It is prominently used in various management studies [23].

\section{CONCLUSION}

According to the literature review, both ELM and stakeholders pressure literature have theorized and empirically demonstrated that specific practices, aimed at developing the firm performance, result in superior environmental and economic performance. Studies in the field of EML have increased interest in maintaining a clean environment, ensuring resource conservation, preventing and reducing harmful environmental impacts, especially in industrial organizations, while encouraging energy savings and reducing wasted resources in the context of sustainable performance development and the role of these practices in improving the overall performance of organizations. Actions to preserve the environment by achieving cooperation and partnership between the organization and its stakeholders. Last, but not least, the integration of ELM practices- stakeholder's 
pressures has a significant chance to add value to the environmental development of the firm sustainability performances.

\section{ACKNOWLEDGMENT}

A special thanks for Palestine Technical University and Al-Quds Open University for supporting this research.

\section{REFERENCES}

[1] EQA. (2019). Draft National strategy for Environmental Awareness and Training (2013-2020). Palestine, Ramallah.

[2] Dubey, R., Dubey, R., Gunasekaran, A., Gunasekaran, A., Papadopoulos, T., \& Papadopoulos, T. (2017). Green supply chain management: theoretical framework and further research directions. Benchmarking: An International Journal, 24(1), 184-218.

[3] Yu, W., Chavez, R., Feng, M., \& Wiengarten, F. (2014). Integrated green supply chain management and operational performance. Supply Chain Management: An International Journal, 19(5/6), 683-696.

[4] Liebetruth, T. (2017). Sustainability in performance measurement and management systems for supply chains. Procedia engineering, 192, 539544.

[5] Shwekeh, A., Zaid, A. A., Saleh, M. W. A., \& Khaleel, M. M. M. (2021). The Impact of Economic Indicators on Food Supply Chain of Palestine. Journal of University of Shanghai for Science and Technology, 23(1), 264275.

[6] Younis, H., Younis, H., Sundarakani, B., Sundarakani, B., Vel, P., \& Vel, $P$. (2016). The impact of implementing green supply chain management practices on corporate performance. Competitiveness Review, 26(3), 216245.

[7] Zhu, Q., Sarkis, J., \& Lai, K.-h. (2013). Institutional-based antecedents and performance outcomes of internal and external green supply chain management practices. Journal of Purchasing and Supply Management, 19(2), 106-117.

[8] Guerci, M., Longoni, A., \& Luzzini, D. (2016). Translating stakeholder pressures into environmental performance-the mediating role of green HRM practices. The International Journal of Human Resource Management, 27(2), 262-289.

[9] Lee, S. M., Tae Kim, S., \& Choi, D. (2012). Green supply chain management and organizational performance. Industrial Management \& Data Systems, 112(8), 1148-1180.

[10] Green Jr, K. W., Zelbst, P. J., Meacham, J., \& Bhadauria, V. S. (2012). Green supply chain management practices: impact on performance. Supply Chain Management: An International Journal, 17(3), 290-305.

[11] Diabat, A., Khodaverdi, R., \& Olfat, L. (2013). An exploration of green supply chain practices and performances in an automotive industry. The International Journal of Advanced Manufacturing Technology, 68(1-4), 949-961. 
[12] Laosirihongthong, T., Adebanjo, D., \& Choon Tan, K. (2013). Green supply chain management practices and performance. Industrial Management \& Data Systems, 113(8), 1088-1109.

[13] Koh, S., Gunasekaran, A., \& Tseng, C. (2012). Cross-tier ripple and indirect effects of directives WEEE and RoHS on greening a supply chain. International Journal of Production Economics, 140(1), 305-317.

[14] Holt, D., \& Ghobadian, A. (2009). An empirical study of green supply chain management practices amongst UK manufacturers. Journal of Manufacturing Technology Management, 20(7), 933-956.

[15] De Giovanni, P. (2012). Do internal and external environmental management contribute to the triple bottom line? International Journal of Operations \& Production Management, 32(3), 265-290.

[16] Eltayeb, T., \& Zailani, S. (2011). Greening Supply Chain through Supply Chain Initiatives towards Environmental Sustainbility. International Journal Environment Science Technology, 2(5), 506-516.

[17] Hofer, C., Cantor, D. E., \& Dai, J. (2012). The competitive determinants of a firm's environmental management activities: Evidence from US manufacturing industries. Journal of Operations Management, 30(1-2), 69-84.

[18] Cheng, J. H., Yeh, C. H., \& Tu, C. W. (2008). Trust and knowledge sharing in green supply chains. Supply Chain Management: An International Journal, 13(4), 283-295.

[19] Li, S., Jayaraman, V., Paulraj, A., \& Shang, K.-c. (2016). Proactive environmental strategies and performance: Role of green supply chain processes and green product design in the Chinese high-tech industry. International journal of production research, 54(7), 2136-2151.

[20] Hong, J., Zhang, Y., \& Ding, M. (2018). Sustainable supply chain management practices, supply chain dynamic capabilities, and enterprise performance. Journal of Cleaner Production, 172, 3508-3519.

[21] Masri, H. A., \& Jaaron, A. A. M. (2017). Assessing green human resources management practices in Palestinian manufacturing context: An empirical study. Journal of Cleaner Production, 143, 474-489.

[22] Hair, Joseph F., Marko Sarstedt, Christian M. Ringle, S. P. G. (2017). Advanced issues in partial least squares structural equation modelling.

[23] Peng, D. X., \& Lai, F. (2012). Using partial least squares in operations management research: A practical guideline and summary of past research. Journal of Operations Management, 30(6), 467-480. 